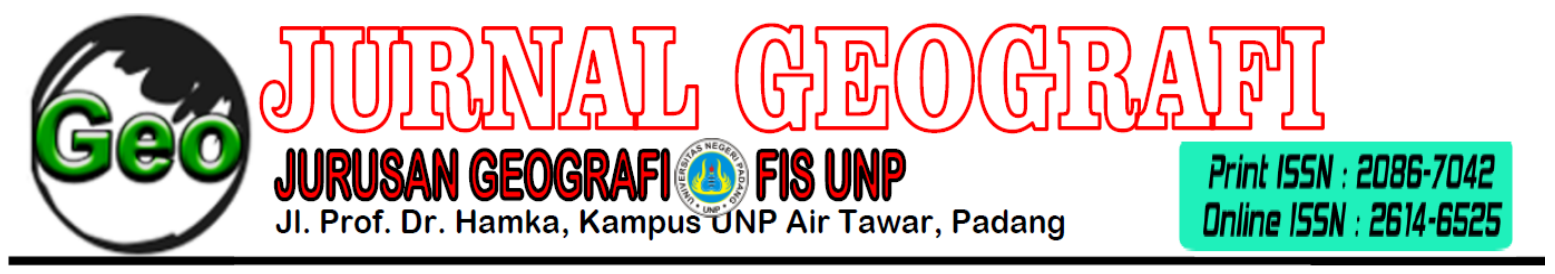

\title{
PENINGKATAN AKTIVITAS DAN HASIL BELAJAR IPS MENGGUNAKAN MEDIA ANIMASI
}

\author{
Oleh: \\ Dedy Miswar, Yarmaidi, Yuniyarsih \\ FKIP Universitas Lampung \\ de_miswar@yahoo.com,
}

\begin{abstract}
This research aimed to: improve the learning activities, and learning outcomes at class VII-1 of SMPN 1 Sungkai Selatan. This research used descriptive method with classroom action research which was conducted in three cycles. The subjects of this research were 36 students from class VII-1 which consist of 20 female students and 16 male students. The data that taken were the result of the end of the cycle and the observation of learning activities and learning outcomes. The result of this research showed that in first cycle, students learning activities reach $52,78 \%$ and where as the results of learning outcomes completeness reached $44,44 \%$. In the second cycle students learning activities increased into $64,58 \%$, and the learning outcomes completeness also increased to $52,78 \%$. In the third cycle which one to be the result of this research showed, students learning activities increased to $75,69 \%$, the percentage of learning outcomes completeness also increased to $80,55 \%$. Based on those result, it can be concluded that teaching through media animation can improve the learning activities, and learning outcomes IPS.
\end{abstract}

\section{Keywords: Learning Activities, Learning Outcomes, Media Animation.}

Abstrak: Penelitian ini bertujuan untuk mengkaji tentang penggunaan media animasi untuk meningkatkan aktivitas, dan hasil belajar IPS peserta didik kelas VII-1 SMPN 1 Sungkai Selatan. Penelitian ini menggunakan metode deskriptif dengan penelitian tindakan kelas yang dilakukan dalam 3 siklus. Subjek dalam penelitian ini adalah 36 peserta didik dari kelas VII-1 yang terdiri dari 20 peserta didik perempuan dan 16 peserta didik laki-laki. Data yang diambil berupa hasil tes akhir siklus dan hasil observasi aktivitas dan belajar Hasil penelitian menunjukan bahwa pada siklus I, aktivitas belajar peserta didik mencapai 52,78\% dan ketuntasan hasil belajar mencapai $44,44 \%$. Pada siklus II aktivitas belajar peserta didik meningkat menjadi $64,58 \%$ dan ketuntasan hasil belajar juga meningkat menjadi 52,78\%. Pada siklus III yang sekaligus menjadi hasil dalam penelitian ini, aktivitas belajar peserta didik meningkat menjadi $75,69 \%$ dan persentase ketuntasan hasil belajar juga ikut meningkat menjadi $80,55 \%$. Berdasarkan hasil penelitian tersebut dapat disimpulkan bahwa penggunaan media animasi dapat meningkatkan aktivitas dan hasil belajar IPS.

Kata Kunci : Aktivitas Belajar, Hasil Belajar, Media Animasi. 


\section{PENDAHULUAN}

Proses belajar mengajar di kelas bertujuan untuk mencapai perubahanperubahan tingkah laku intelektual, moral maupun sosial pada siswa. Siswa berinteraksi dengan ling-kungan belajar diatur oleh guru melalui proses pembelajaran. Proses pembelajaran yang terjadi di dalam kelas ditentukan oleh beberapa komponen pembelajaran, antara lain: tujuan pembel-ajaran, materi/bahan ajar, metode dan media, evaluasi, peserta didik/siswa, pendidik/guru (Toto Ruhimat, dkk., 2011). Selain itu, proses belajar siswa dipengaruhi oleh lingkung-an sosial keluarga, lingkungan sosial sekolah, sosial masyarakat, lingkungan alamiah, serta faktor instrumental (gedung sekolah, alat-alat belajar, fasilitas belajar, kurikulum, peraturan sekolah, buku panduan, serta silabi (Baharuddin \& Esa, 2010). Dengan demikian tentu harus diupayakan suatu proses pembelajaran yang dapat menjembatani berbagai faktor-faktor terutama kelemahan-kelemahan yang ada, agar tercapai tujuan pendidikan.

Kegiatan pembelajaran merupakan kegiatan yang paling pokok yang harus dilaksanakan oleh guru dalam rangka menyampaikan berbagai pesan pada siswa, dengan tujuan agar siswa dapat menguasai pengetahuan, kecakapan, keterampilan dan sikap sesuai dengan tujuan pembelajaran yang disajikan guru, serta tujuan yang digariskan dalam pelaksanaan kurikulum. Oleh karena itu, guru di dalam proses belajar mengajar diharapkan mempersiapkan perangkat pembelajaran seperti rencana pembelajaran, alat peraga, media, metode, alat evaluasi, serta pendekatan yang sesuai, sehingga diharapkan tujuan pembelajaran dapat tercapai secara maksimal.

Salah satu keprihatinan yang dilontarkan banyak kalangan adalah mengenai rendahnya kualitas pendidikan yang dihasilkan oleh lembaga-lembaga pendidikan formal. Dalam hal ini, yang menjadi kambing hitam adalah guru dan lembaga pendidikan tersebut, orang tua tidak memandang aspek keluarga dan kondisi lingkungannya. Padahal lingkungan keluarga dan masyarakat sekitar sangat menentukan terhadap keberhasilan pendidikan.

Peningkatan kualitas pendidikan di sekolah dapat dilakukan dengan beberapa cara, diantaranya adalah peningkatan bekal awal untuk siswa baru, peningkatan kualitas kompetensi guru, peningkatan kurikulum, peningkatan kualitas pembelajaran, penilaian hasil belajar siswa dan penyediaan bahan ajar serta fasilitas yang memadai termasuk media pembelajaran.

Salah satu upaya pemerintah untuk meningkatkan kualitas pendidikan di Indonesia adalah dengan menerapkan Kurikulum Tingkat Satuan Pendidikan. Di dalam KTSP, kegiatan pembelajaran dirancang dan dikembangkan berdasarkan karakteristik kompetensi dasar, standar kompetensi, potensi peserta didik, daerah dan lingkungan setiap kegiatan bertujuan untuk pencapaian kompetensi dasar yang diuraikan dalam indikator dengan intensitas kompetensi yang beragam, standar kompetensi dan kompetensi dasar Ilmu Pengetahuan Sosial (IPS) di Sekolah Menengah Pertama (SMP), meliputi bahan kajian: Sosiologi, 
Sejarah, Geografi, Ekonomi. Bahan kajian itu menjadi mata pelajaran Ilmu Pengetahuan Sosial (IPS).

Mata Pelajaran IPS merupakan pembelajaran terpadu yaitu pembelajaran yang dilakukan secara holistik (menyeluruh) dan autentik (asli). Adapun tujuannya agar peserta didik dapat berfikir kritis, berfikir kreatif dan berfikir mutakhir. Mata pelajaran IPS bertujuan mengembangkan potensi peserta didik agar peka terhadap masalah sosial yang terjadi di masyarakat, memiliki sikap mental positif terhadap perbaikan segala ketimpangan yang terjadi, dan terampil mengatasi setiap masalah yang terjadi sehari-hari baik yang menimpa dirinya sendiri maupun yang menimpa kehidupan masyarakat (Nursid Sumaatmaja, 1996).

Melalui pembelajaran terpadu peserta didik dapat memperoleh pengalaman langsung, sehingga dapat menambah kekuatan untuk menerima, menyimpan, dan memproduksi kesan-kesan tentang hal-hal yang dipelajarinya. Dengan demikian, peserta didik terlatih untuk mendapat menemukan sendiri berbagai konsep yang dipelajari secara holistik, bermakna, otentik, dan aktif. Fakta di lapangan, pendidikan yang seharusnya berjalan efektif di sekolah tidak selamanya sesuai dengan apa yang diharapkan. Terindikasi sebagian besar peserta didik tidak mengikuti pembelajaran IPS dengan baik.

Banyak peserta didik yang tidak terlibat aktif dalam pembelajaran IPS di kelas secara maksimal, rendahnya hasil belajar, rendahnya aktivitas belajar, kurangnya efektivitas belajar, kurang lengkapnya fasilitas belajar, rendahnya hasil belajar peserta didik, peserta didik merasa bosan di dalam kelas, serta kurangnya keterampilan guru dalam memilih media yang tepat sehingga mengakibatkan perestasi belajar peserta didik menjadi kurang baik atau kurang maksimal. Hal tersebut menunjukkan ada permasalahan dalam pembelajaran IPS diantaranya aktivitas belajar peserta didik yang rendah seperti masih banyak peserta didik yang masih sibuk sendiri di dalam kelas seperti berkunjung ke kelompok lain, mengerjakan tugas lain, mengganggu siswa lain, mengobrol dengan teman, dan keluar kelas, tidak memperhatikan penjelasan guru, tidak aktif bertanya, tidak bersemangat dalam pembelajaran, karena merasa bosan di dalam kelas, rendahnya hasil belajar karena banyak peserta didik yang mendapat nilai di bawah ketuntasan hasil belajar, masih kurangnya media pembelajaran yang digunakan seperti penggunaan media animasi belum pernah diterapkan dalam pembelajaran IPS dan masalah pada guru adalah tindakan pembelajaran yang kurang tepat.

Sekolah Menengah Pertama Negeri 1 Sungkai Selatan merupakan salah satu sekolah yang terletak di Desa Ketapang, Kecamatan Sungkai Selatan, Kabupaten Lampung Utara. Di sekolah ini jumlah kelas VII sebanyak enam kelas, menurut guru mata pelajaran IPS banyak peserta didik yang masih memiliki hasil belajar yang rendah hal ini disebabkan karena aktivitas belajar IPS rendah, serta masih minimnya media pembelajaran yang digunakan guru dalam pembelajaran IPS sehingga mempengaruhi nilai belajar peserta didik. Banyak peserta didik yang belum tuntas dalam pembelajaran IPS. Peserta 
didik dinyatakan lulus atau tuntas jika nilai IPS $\geq 72$ atau peserta didik mendapat nilai 72 dan belum dinyatakan lulus atau tuntas jika nilai IPS $\leq 72$. Maka dari itu, diperlukan pembelajaran yang tepat serta penggunaan media pembelajaran yang tepat dan menarik sehingga peserta didik memiliki aktivitas belajar yang tinggi sehingga dapat mempengaruhi dan meningkatkan hasil belajar.

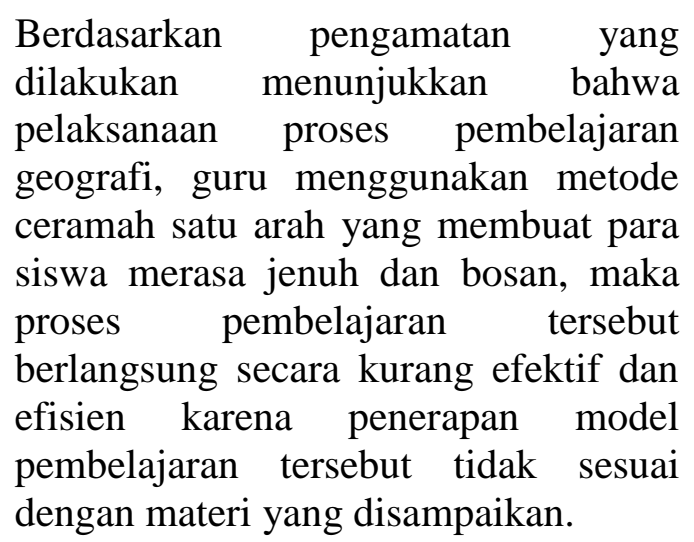

Banyaknya peserta didik yang mendapat nilai di bawah KKM merupakan salah satu masalah yang dihadapi guru dalam pembelajaran. Guna meningkatkan kualitas dan memperbaiki proses pembelajaran maka dapat digunakan media pembelajaran dan pembelajaran yang tepat sehingga dapat membantu peserta didik untuk terlibat aktif dalam proses pembelajaran IPS.

Proses belajar dan interaksi mengajar tidak harus dari pengalaman langsung, tetapi dimulai dengan jenis pengalaman yang paling sesuai dengan kebutuhan dan kemampuan kelompok peserta didik yang dihadapi dengan mempertimbangkan situasi belajar. Penggunaan media pembelajaran dapat membantu peserta didik dalam belajar suatu konsep agar lebih mudah dan lebih menarik serta membuat peserta didik terlibat aktif dapat di gunakan media animasi.

Media animasi merupakan segala sesuatu yang dapat digunakan untuk menyalurkan pesan dari pengirim kepada penerima sehingga digunakan untuk menyalurkan pesan dari pengirim kepada penerima sehingga dapat merangsang pikiran, perasaan, minat, dan perhatian sedemikian rupa sehingga proses belajar terjadi (Sardiman, 2002).

Menurut Gagne yang dikutip dalam Sardiman (2002), media adalah berbagai jenis komponen dalam lingkungan siswa yang dapat merangsangnya untuk berfikir. Dengan menggunakan media animasi maka proses pembelajaran menjadi lebih menarik sehingga peserta didik dapat terangsang untuk berfikir kritis dan terlibat aktif dalam pembelajaran IPS serta memiliki ketertarikan dalam pembelajaran IPS, sehingga masalah dalam pembelajaran IPS dikelas dapat di atasi.

Masalah ini perlu di teliti, mengingat pentingnya media pembelajaran yang menarik sehingga dapat meningkatkan aktivitas dan hasil belajar peserta didik yaitu salah satunya dengan menggunakan media animasi pendidikan guna menunjang atau meningkatkan hasil belajar peserta didik serta dapat memperbaiki proses pembelajaran di dalam kelas. Bahan pembelajaran ini diberikan guna menambah pemahaman peserta didik akan materi pembelajaran IPS Terpadu yang disampaikan guru karena peserta didik dapat melihat dan mendengar 
secara langsung materi yang terkait dengan pembelajaran IPS.

Materi yang disampaikan yaitu materi mengenai Atmosfer. Dengan Standar Kompetensi mendeskripsikan gejalagejala yang terjadi di atmosfer serta dampaknya terhadap kehidupan pada Kompetensi Dasar 4.4 mendeskripsikan gejala-gejala yang terjadi di atmosfer dan hidrosfer serta dampaknya terhadap kehidupan. Atmosfer merupakan lapisan udara yang menyelimuti bumi, dalam pembelajaran selama ini yang diberikan guru kepada peserta didik masih banyak yang belum memahami materi tersebut sehingga banyak peserta didik yang mendapat nilai di bawah KKM.

Selain itu, berangkat dari masalah yang dihadapi guru di dalam kelas dan dari ketertarikan peserta didik terhadap animasi baik berupa gambar, video atau menonton film animasi, sehingga perlu digunakan media animasi guna meningkatkan aktivitas, dan hasil belajar peserta didik. Media animasi bertujuan agar dapat menarik perhatian peserta didik untuk memperhatikan guru. Selain itu, media animasi tersebut dapat membantu meningkatkan aktivitas, dan hasil belajar peserta didik pada saat pembelajaran berlangsung.

\section{METODE}

Penelitian ini menggunakan penelitian tindakan kelas (classroom action research) yang dilandasi pada prinsip "natural setting", situational, dan berpijak pada realitas lapangan. Kekuatan penelitian ini terletak pada analisis yang dilakukan setelah dilakukan praktik.
Penelitian ini merupakan penggabungan antara tindakan dengan prosedur ilmiah dalam rangka untuk memahami sambil ikut serta dalam proses perbaikan. McNiff (1992) mengatakan bahwa penelitian tindakan ini merupakan satu jenis penelitian refleksi diri dalam situasi sosial yang berusaha mengatasi permasalahan secara langsung. Penelitian tindakan dipandang lebih sesuai untuk bidang pendidikan, karena sifat objek dan sarananya yang beragam serta dinamis. Stephen Kemmis, dalam Hopkins (1993) mengatakan bahwa in education, action research has been employed in school based curriculum development, profess-sional development, school improvement program, and system planning and policy development.

Jadi, penelitian tindakan kelas merupakan suatu metode penelitian yang berorientasi pada pengembangan atau penyempurnaan dalam mengatasi suatu permasalahan secara langsung melalui suatu tindakan dan refleksi diri yang didasarkan pada hasil kajian. Oleh karenanya, prosedur dalam penelitian ini menggunakan model siklus, sebagaimana yang dikemukakan oleh Lewins dan McNiff (1995) menggambarkan action research as a spiral of steps, each step had four stages; planning, acting, observing, and reflecting.

Penelitiaan ini berlangsung secara siklik, yang terdiri dari 3 (tiga) siklus, yang setiap siklis terdiri dari perencanaan, pelaksanaan tindakan , observasi dan refleksi, dengan perbedaan yang dapat dilihat pada tabel berikut: 
Tabel 1. Perencanaan, Pelaksanaan Tindakan, Observasi dan Refleksi

\begin{tabular}{|c|c|c|c|}
\hline $\begin{array}{l}\text { Kegiatan } \\
\text { setiap siklus }\end{array}$ & Siklus 1 & Siklus 2 & Siklus 3 \\
\hline Perencanaan & 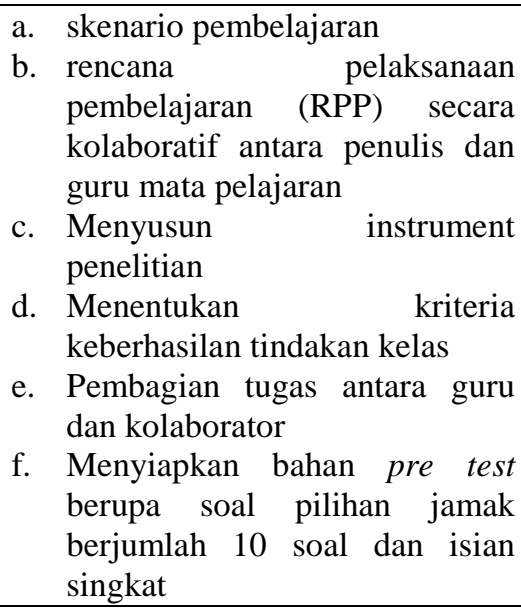 & $\begin{array}{l}\text { skenario } \\
\text { tindakan } \\
\text { berdasarkan hasil } \\
\text { refleksi pada } \\
\text { siklus 1, dengan } \\
\text { perencanaan } \\
\text { yang sama } \\
\text { seperti siklus } 1\end{array}$ & $\begin{array}{lr}\text { skenario tindakan } \\
\text { berdasarkan hasil } \\
\text { refleksi pada siklus } 2 \\
\text {, dengan perencanaan } \\
\text { yang sama seperti } \\
\text { siklus 1 }\end{array}$ \\
\hline Tindakan & $\begin{array}{l}\text { a. Membuka pelajaran dengan } \\
\text { memberikan motivasi dan } \\
\text { apresiasi. } \\
\text { b. Mengadakan pre test } \\
\text { c. Menyampaikan materi melalui } \\
\text { media animasi yang sesuai } \\
\text { dengan standar kompetensi } \\
\text { pembelajaran IPS. } \\
\text { d. Membagi peserta didik dalam } \\
\text { kelompok diskusi kecil masing- } \\
\text { masing yang beranggotakan 5-6 } \\
\text { orang. } \\
\text { e. Memberikan } \\
\text { peserta didik besempatan } \\
\text { mengenai tanggapan mereka } \\
\text { terhadap materi yang telah } \\
\text { ditayangkan. } \\
\text { f. Peserta didik menyampaikan } \\
\text { hasil diskusi kelompok kecil } \\
\text { didepan kelas. } \\
\text { g. Peserta didik yang berasal dari } \\
\text { kelompok lain diberikan } \\
\text { kesempatan untuk menanggapi, } \\
\text { bertanya, dan mengemukakan } \\
\text { pendapat. } \\
\text { h. Menyimpulkan hasil diskusi }\end{array}$ & $\begin{array}{l}\text { tindakan } \\
\text { berdasarkan hasil } \\
\text { refleksi pada } \\
\text { siklus I, dengan } \\
\text { tindakan yang } \\
\text { sama seperti } \\
\text { siklus 1, namun } \\
\text { pada siklus } 2 \\
\text { Guru dan penulis } \\
\text { bersama siswa } \\
\text { menyimpulkan } \\
\text { hasil diskusi } \\
\text { menggunakan } \\
\text { model dan } \\
\text { pembelajaran } \\
\text { kooperatif dan } \\
\text { media animasi }\end{array}$ & $\begin{array}{l}\text { tindakan berdasarkan } \\
\text { hasil refleksi pada } \\
\text { siklus } 2 \text {, dengan } \\
\text { tindakan yang sama } \\
\text { seperti siklus } 2 .\end{array}$ \\
\hline Observasi & $\begin{array}{lr}\text { dilaksanakan selama } & \text { proses } \\
\text { kegiatan pembelajaran. } & \text { Agar } \\
\text { pelaksanaan observasi } & \text { dapat } \\
\text { berjalan terarah maka perlu } \\
\text { disiapkan lembar observasi dengan } \\
\text { cara memberikan post test untuk } \\
\text { melihat ketercapaian KD. }\end{array}$ & $\begin{array}{l}\text { Sama dengan } \\
\text { siklus I }\end{array}$ & Sama dengan siklus 2 \\
\hline
\end{tabular}




\begin{tabular}{|l|l|l|l|}
\hline Refleksi & $\begin{array}{l}\text { Dilakukan bersama guru mata } \\
\text { pelajaran untuk mengetahui hasil } \\
\text { pada siklus I dan permasalahan } \\
\text { yang terjadi apabila hasil tidak } \\
\text { siklus 1 }\end{array}$ & & \\
& $\begin{array}{l}\text { Sesuai dengan harapan. Hasil } \\
\text { refleksi siklus I, akan digunakan } \\
\text { untuk siklus selanjutnya. }\end{array}$ & & \\
\hline
\end{tabular}

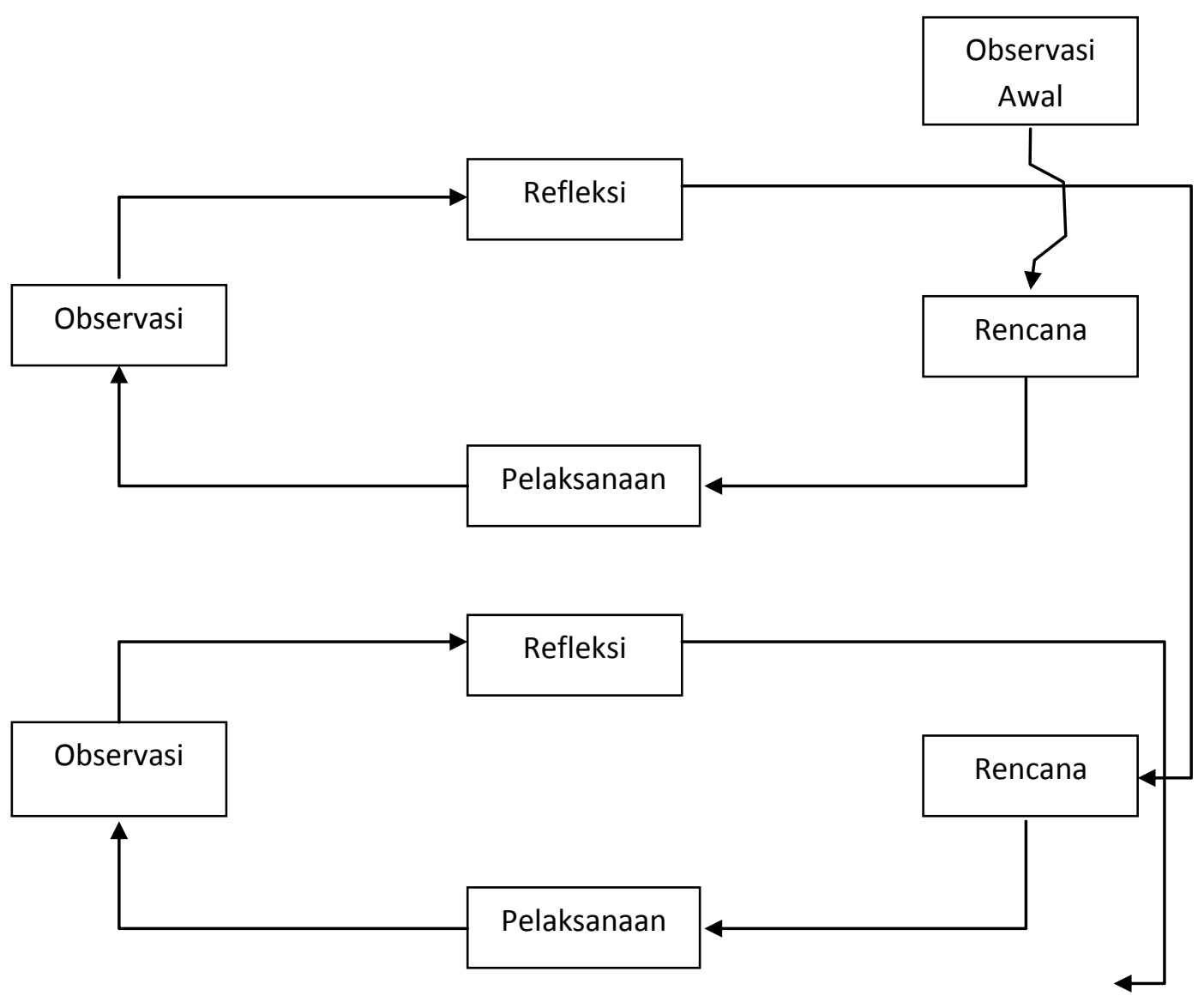

Gambar 1 Siklus Penelitian

(Sumber: Kemmis dan Taggart, 1998)

Analisis data yang dilakukan dalam penelitian adalah dengan menggunakan persentase nilai aktivitas dan hasil belajar siswa kelas VII-1 SMPN 1 Sungkai Selatan . 


\section{HASIL DAN PEMBAHASAN}

\section{Media Animasi Untuk Meningkatkan Aktivitas Belajar}

\section{Aktivitas Belajar Siklus I}

Menurut Sardiman (2002), Media animasi adalah segala sesuatu yang dapat digunakan untuk menyalurkan pesan dari pengirim kepada penerima sehingga dapat merangsang pikiran, perasaan, minat dan perhatian sedemikian rupa sehingga proses belajar terjadi. Media animasi dapat berupa gambar, video dan film. Media animasi seperti video dan film adalah media pembelajaran yang bertujuan untuk memaksimalkan efek audiovisual sehingga dapat memberikan interaksi berkelanjutan dan menambah pemahaman bahan ajar meningkat dan lebih mempertinggi efektivitas dan efesiensi dalam pencapaian tujuan pembelajaran.

Pada tahap pelaksanaan peserta didik diminta untuk mengamati video atau film "Ozzy Ozon" yang ditampilkan dimana pada video atau film tersebut menceritakan mengenai petualangan ozzy yaitu makhluk pelindung lapisan ozon bumi yang jatuh ke bumi akibat gangguan CFC (Cloro Floro Carbon).kegiatan diskusi penulis dan guru mata pelajaran mengamati peserta didik untuk mengetahui bagaimana aktivitas dan hasil belajar peserta didik dalam memecahkan masalah, membantu peserta didik jika mendapat kesulitan dan menuntun siswa untuk membuat kesimpulan akhir yang nantinya akan digunakan peserta didik untuk presentasi kelompok di depan kelas setelah selesai berdiskusi terkait dengan materi lapisan atmosfer dengan media animasi atmosfer khususnya masalah kerusakan ozon dan dampaknya terhadap kehidupan di muka bumi.

Selama proses pembelajaran dimulai dan peserta didik melakukan diskusi kelompok, penulis dan guru mata pelajaran menilai aktivitas belajar peserta didik dengan menggunakan lembar observasi yang telah disediakan. Dikarenakan jam pelajaran sudah berakhir dan pembelajaran IPS dilaksanakan pada jam terakhir sehingga sebagian peserta didik sudah sibuk ingin pulang kerumah, selanjutnya peneliti bersama guru mitra dan peserta didik menyimpulkan materi pembelajaran yang diperoleh pada pertemuan ini dan menutup mata pelajaran pada pertemuan siklus I.

Data hasil observasi aktivitas peserta didik dalam pembelajaran IPS dapat dilihat pada tabel 2, berikut:

\section{Tabel 2. Data Hasil Observasi Aktivitas Peserta Didik pada Siklus I}

\begin{tabular}{|c|l|r|}
\hline No. & \multicolumn{1}{|c|}{ Aktivitas Belajar } & Pesentase (\%) \\
\hline 1 & $\begin{array}{l}\text { Rendah (Jumlah aktivitas Off Task } \leq 1 \text { dan On } \\
\text { task) }\end{array}$ & 22,22 \\
\hline 2 & $\begin{array}{l}\text { Sedang (Jumlah aktivitas Off Task 2 dan On } \\
\text { task) }\end{array}$ & $\begin{array}{l}\text { Tinggi (Jumlah aktivitas Off Task } \geq 3 \text { dan On } \\
\text { task) }\end{array}$ \\
\hline 3 & \begin{tabular}{l} 
100,00 \\
\hline
\end{tabular}
\end{tabular}

Sumber: Hasil Pengolahan Data Lembar Observasi Penilaian. 
Berdasarkan tabel di atas, dapat dilihat secara keseluruhan bahwa peningkatan aktivitas belajar yang dilakukan peserta didik pada siklus 1 masih rendah, hal ini dapat dilihat berdasarkan persentase peningkatan grafik aktivitas belajar tinggi yang hanya mencapai $52,78 \%$ dan rendah sebanyak $22,22 \%$ sehingga masih belum terlihat peningkatan aktivitas belajar secara optimal.

Pada siklus ini dapat dikatakan belum optimal dikarenakan masih sedikit siswa yang memiliki indikator aktivitas belajar tinggi. Berdasarkan persentase pada pengamatan pertemuan pertama dan pertemuan kedua pada siklus I. Jika dilihat berdasarkan pengamatan pada siklus ini, aktivitas off task yang tergolong tinggi terlihat pada aktivitas berkunjung ke kelompok lain, mengerjakan tugas lain, mencoba menarik perhatian (masih ribut), dan keluar kelas. Sedangkan aktivitas off task sedang yaitu mengganggu peserta didik lain, meminjam peralatan, dan aktivitas off task rendah yaitu berbicara tidak relevan dan mengobrol ketika guru menjelaskan materi pembelajaran di kelas.

Aktivitas off task masih terlihat tinggi pada saat proses pembagian kelompok dan tugas kelompok, awal proses diskusi, dan saat presentasi di depan kelas dimana banyak peserta didik yang berkunjung ke kelompok lain, mengerjakan tugas lain, mencoba menarik perhatian (masih ribut), dan keluar kelas. Hal ini disebabkan pada proses pembelajaran masih banyak terdapat kekurangan-kekurangan seperti: penulis sebagai guru mitra dan guru mata pelajaran masih belum dapat menguasai kelas secara baik sehingga kurang kondusif, dan peserta didik masih kurang dibimbing untuk bekerjasama dengan kelompok dalam kegiatan diskusi.

Persentase aktivitas on task peserta didik dalam pembelajaran IPS di dalam kelas, didapat pada memperhatikan pelajaran dan mengerjakan tugas yang di berikan, kegiatan mencatat materi atau topik dan terdapat pada kegiatan mengajukan pertanyaan sesuai topik yang di bahas. Peserta didik belajar menggunakan media animasi menjadi lebih fokus dan memperhatikan penjelasan materi yang disajikan walaupun masih banyak peserta didik yang masih melakukan aktivitas off task sehingga hasil yang di dapat belum tercapai.

Aktivitas ini terlihat pada saat peserta didik mengajukan pertanyaan masih banyak yang belum paham akan materi yang disampaikan dan pada pertemuan siklus I masih banyak peserta didik yang malu-malu untuk bertanya sehingga masih banyak kekurangan yang harus diperbaiki pada siklus selanjutnya guna meningkatkan aktivitas belajar peserta didik sehingga belajar menjadi terarah.

\section{Aktivitas Belajar Siklus II}

Data hasil observasi aktivitas belajar peserta didik siklus II pada pertemuan pertama dan kedua, secara keseluruhan data aktivitas pesertadidik baik off task dan on task pada siklus II dapat dilihat pada tabel 3, berikut: 
Tabel 3. Data Hasil Aktivitas Belajar Peserta Didik Pada Siklus II

\begin{tabular}{|c|l|r|}
\hline No. & \multicolumn{1}{|c|}{ Aktivitas Belajar } & Pesentase (\%) \\
\hline 1 & Siklus I & 52,78 \\
\hline 2 & Siklus II & 64,58 \\
\hline
\end{tabular}

Sumber: Hasil Pengolahan Data Lembar Observasi Penilaian.

Berdasarkan tabel di atas, dapat dilihat secara keseluruhan bahwa peningkatan aktivitas belajar yang dilakukan peserta didik pada siklus II mengalami peningkatan cukup memuaskan, hal ini dapat dilihat berdasarkan persentase pada siklus I yang mencapai $52,78 \%$ dan pada siklus II meningkat menjadi $64,58 \%$. Mulai terlihat peningkatan aktivitas belajar secara optimal, pada siklus ini dapat dikatakan sudah mulai optimal hal ini dikarenakan sudah mulai terdapat banyak peserta didik yang memiliki indikator aktivitas belajar tinggi. Aktivitas ini mengalami peningkatan dari Siklus I, terlihat pada saat peserta didik mengajukan pertanyaan masih banyak yang belum paham akan materi yang disampaikan dan pada pertemuana siklus II peserta didik sudah mulai terbiasa belajar dengan menggunakan media animasi dan sudah terlihat juga suasana pembelajaran yang mulai kondusif, efektif dan menyenangkan.

\section{Aktivitas Belajar Siklus III}

Data hasil observasi aktivitas peserta didik dalam pembelajaran IPS yang di laksanakan dalam dua kali pertemuan dalam siklus III, secara keseluruhan hasil observasi aktivitas belajar pada siklus III dapat dilihat pada tabel 4 , berikut:

Tabel 4. Data Hasil Aktivitas Belajar Peserta Didik Pada Siklus III

\begin{tabular}{|c|l|r|}
\hline No. & \multicolumn{1}{|c|}{ Aktivitas Belajar } & Pesentase (\%) \\
\hline 1 & Siklus I & 52,78 \\
\hline 2 & Siklus II & 64,58 \\
\hline 3 & Siklus III & 75,69 \\
\hline
\end{tabular}

Sumber: Hasil Pengolahan Data Lembar Observasi Penilaian.

Berdasarkan tabel di atas, dapat dilihat adanya peningkatan aktivitas belajar pada setiap siklusnya. Peningkatan aktivitas belajar peserta didik yang pada awalnya hanya mencapai $52,78 \%$, meningkat menjadi $64,58 \%$ pada siklus kedua dan meningkat menjadi $75,69 \%$ pada siklus ketiga. Jumlah ini sudah tergolong baik dan berarti dalam pembelajaran IPS yang telah dilaksanakan, kondisi pembelajaran yang dilakukan sangat baik karena peserta didik menjadi lebih aktif dan fokus terhadap materi.

\section{HASIL DAN PEMBAHASAN}

\section{Media Animasi Untuk Meningkatkan Hasil Belajar}

\section{Hasil Belajar Siklus I}

Indikator keberhasilan hasil belajar dalam penelitian ini akan ditinjau dari persentase ketuntasan hasil belajar siswa. Jika persentase siswa tuntas (dengan nilai $\geq 72$ ) setiap siklus meningkat dan pada akhir siklus tiga siswa yang mendapat nilai $\geq 72$ sebesar $70 \%$ atau lebih maka dapat dikatakan bahwa penelitian 
tindakan ini berhasil. Perolehan hasil

dapat dilihat pada tabel 5, berikut:

belajar peserta didik pada siklus 1 ,

Tabel 5. Perolehan Nilai pretest dan posttest peserta didik

\begin{tabular}{|l|l|r|r|r|}
\hline No. & \multicolumn{1}{|c|}{ Nilai } & \multicolumn{1}{c|}{ Nilai Max. } & \multicolumn{1}{c|}{ Nilai Min. } & \multicolumn{1}{c|}{ Rerata } \\
\hline 1 & Pre Test & 65 & 0 & 27,64 \\
\hline 2 & Post Test & 80 & 40 & 65,56 \\
\hline
\end{tabular}

Sumber: Hasil Pengolahan Nilai Pre Test dan Post Test.

Pada tes awal pada siklus 1 diperoleh rata-rata nilai peserta didik yaitu 27,64 dengan nilai tertinggi yaitu 65 dan untuk yang terendah yaitu 0 artinya semua peserta didik tidak memenuhi KKM, sedangkan untuk nilai posttest diperoleh rata-rata nilai peserta didik yaitu 65,56 dengan nilai tertinggi yaitu 80 dan untuk yang terendah yaitu 40 artinya masih banyak peserta didik yang tidak memenuhi KKM.

Hasil Pretest dan Posttest peserta didik kelas VII-1 masih belum optimal untuk nilai Pretest berkisar antara angka 0-65 dan untuk nilai Posttest berkisar antara 40-80 dan persentase ketuntasan hasil belajar pada siklus 1 mencapai $44,44 \%$.

Pada siklus I, dalam pembelajaran dengan menggunakan media animasi guru masih mengalami kesulitan merencanakan kegiatan yang akan berlangsung karena guru belum sepenuhnya dapat mengontrol peserta didik dan guru juga belum mampu mengelola waktu sehingga mengakibatkan perencanaan pembelajaran masih kurang tepat dan kurang maksimal. Dari segi pelaksanaan pembelajaran guru belum dapat melaksanakan pembelajaran sesuai dengan perencanaan yang telah ditetapkan terutama pengalokasian waktu dengan baik sehingga pembelajaran yang dilakukan masih mengalami banyak hambatan.
Aktivitas yang diamati dalam kegiatan pembelajaran dengan menggunakan media animasi dilihat baik pada aktivitas off task dan on task. Aktivitas off task yang terdiri dari indikator berbicara tidak relevan dengan tugas yang diberikan, berkunjung ke kelompok lain, mengerjakan tugas lain, menganggu siswa lain, mencoba menarik perhatian/mengobrol dengan teman, meminjamkan peralatan dan keluar kelas. Sedangkan aktivitas on task yang terdiri dari indikator memperhatikan penjelasan topik atau materi, mencatat topik atau materi, mengerjakan tugas yang diberikan oleh guru, mengajukan pertanyaan sesuai topik materi yang di bahas. Persentase peserta didik yang aktif dalam pembelajaran dengan menggunakan media animasi mengalami peningkatan. Hal ini dikarenkan dalam tiap siklusnya diadakan refleksi dari hasil belajar yang diperoleh kemudian dilakukan perencanaan ulang sehingga pembelajaran mengalami peningkatan.

Azhar Arsyad (2011) mengemukakan bahwa penggunaan media pembelajaran pada tahap orientasi pembelajaran akan sangat membantu keefektifan proses pembelajaran dan penyampaian pesan dan isi pembelajaran pada saat itu. Selain membangkitkan motivasi dan minat peserta didik, media pembelajaran juga 
dapat membantu peserta didik meningkatkan pemahaman, menyajikan data dengan menarik dan terpercaya, memudahkan penafsiran data, dan memadatkan informasi.

Penggunaan media pembelajaran berupa media animasi dapat memperlancar interaksi antara guru dengan siswa sehingga kegiatan pembelajaran lebih efektif dan efisien. Media animasi yang ditampilkan pada setiap pertemuan dapat membantu peserta didik menyerap materi belajar lebih mandalam dan utuh. Bila dengan mendengar informasi verbal dari guru saja, peserta didik kurang memahami pelajaran, tetapi jika diperkaya dengan kegiatan melihat, menyentuh, merasakan dan mengalami sendiri melalui media pemahaman peserta didik akan lebih baik. Peran penggunaan media animasi sangat berpengaruh dalam menunjang proses pembelajaran yang dilakukan di sekolah, baik itu untuk peserta didik, guru, maupun dalam proses belajar mengajar itu sendiri.

\section{Hasil Belajar Siklus II}

Perolehan hasil belajar berdasarkan nilai pretest dan posttest peserta didik pada siklus II, dapat dilihat pada tabel 6, berikut:

Tabel 6. Perolehan Nilai pre test dan post test peserta didik

\begin{tabular}{|l|l|r|r|r|r|}
\hline \multirow{2}{*}{ No. } & \multirow{2}{*}{ Nilai } & \multicolumn{2}{|c|}{ Siklus I } & \multicolumn{2}{c|}{ Siklus II } \\
\cline { 3 - 6 } & & Pretest & \multicolumn{1}{c|}{ Posttest } & \multicolumn{1}{c|}{ Pretest } & Posttest \\
\hline 1 & Max. & 65 & 80 & 80 & 85 \\
\hline 2 & Min. & 0 & 40 & 45 & 50 \\
\hline $\mathbf{3}$ & Rerata & $\mathbf{2 7 , 6 4}$ & $\mathbf{6 5 , 5 6}$ & $\mathbf{6 1 , 9 4}$ & $\mathbf{6 9 , 6 9}$ \\
\hline
\end{tabular}

Sumber: Hasil Pengolahan Nilai Pre Test dan Post Test Siklus I dan II.

Berdasrkan pada tabel di atas bahwa tes awal pada siklus I, diperoleh rata-rata nilai peserta didik yaitu 27,64 dengan nilai tertinggi yaitu 65 dan untuk yang terendah yaitu 0 artinya semua peserta didik tidak memenuhi KKM, sedangkan untuk nilai pretest pada siklus II diperoleh rata-rata nilai peserta didik yaitu 61,94 dengan nilai tertinggi yaitu 80 dan untuk yang terendah yaitu 45 artinya masih banyak peserta didik yang tidak memenuhi KKM, namun pretest yang dilaksanakan pada siklus II mengalami peningkatan ketuntasan hasil belajar jika dibandingkan dengan siklus sebelumnya begitupun dengan hasil posttest peserta didik yang mengalami peningkatan dari siklus sebelumnya dimana dari 36 peserta didik di kelas
VII-1 terdapat 19 peserta didik yang mencapai KKM dan 17 peserta didik yang tidak mencapai KKM.

Hasil Pretest dan Posttest peserta didik kelas VII-1 masih sudah mengalami peningkatan jika dibandingkan dengan siklus sebelumnya dan persentase ketuntasan hasil belajar pada siklus II mencapai $52,78 \%$.

Media animasi dapat membantu peserta didik dalam memahami konsep pembelajaran cuaca dan iklim. Hal ini, tentunya merupakan suatu peningkatan dan suatu keberhasilan yang baik karena di siklus kedua ini peserta didik sudah mulai terbiasa dan paham dengan materi yang disampaikan menggunakan media animasi 
khususnya pada materi cuaca dan iklim.

Peningkatan dalam perencanaan dan pelaksanaan pembelajaran lebih baik dari siklus I. Hal ini dikarenakan peserta didik sudah mulai terbiasa belajar dengan menggunakan media pembelajaran. Pembelajaran pada siklus ini mengalami sedikit peningkatan. Peserta didik dan guru sudah mulai terbiasa menggunakan media animasi yang digunakan sehingga lebih mudah dalam melaksanakannya. Sehingga aktivitas belajar peserta didik yang diperoleh sudah mengalami peningkatan namun belum maksimal. Pembelajaran yang dilaksanakan sudah lebih baik dan persentase keaktifan peserta didik juga mengalami peningkatan.

Munadi, Yudhi (2010) yang menyatakan bahwa "tujuan pemanfaatan media dalam proses pembelajaran adalah untuk mengefektifkan dan mengefisiensikan proses pembelajaran itu sendiri". Dari pernyataan tersebut dapat diketahui hasil pelaksanaan pembelajaran dengan menggunakan media pembelajaran berupa media animasi yang menjadi tujuan pembelajaran belum sepenuhnya tercapai.

Penggunaan media animasi pada siklus ini dapat meningkatkan Aktivitas belajar peserta didik terhadap mata pelajaran IPS hal ini dapat dilihat berdasarkan peningkatan indiaktor aktivitas peserta didik seperti mulai membudaya ketertarikan untuk bertanya dan manjawab, mulai membudaya untuk tampil di depan kelas, menghargai pendapat teman, bergembira, bersungguh-sunguh dalam belajar, bersemangat dan bekerja sama denga kelompok. Hal ini dikarenakan penulis dan guru selalu memberikan semangat berupa yel-yel, dorongan dan motivasi kepada peserta didik untuk selalu aktif dalam kegiatan pembelajaran IPS di dalam kelas. Pada siklus ini hasil yang didapatkan masih belum maksimal akan tetapi sudah mengalami peningkatan dari siklus sebelumnya.

Menurut Azhar Arsyad (2011), mengemukakan beberapa manfaat praktis dari penggunaan media pembelajaran di dalam proses belajar mengajar antara lain media pembelajaran seperti media animasi dapat memberikan kesamaan pengalaman kepada peserta didik tentang peristiwa-peristiwa di lingkungan mereka, serta memungkinkan terjadinya interaksi langsung dengan guru, masyarakat, dan lingkungannya misalnya melalui karyawisata, kunjungan ke museum atau kebun binatang.

\section{Hasil Belajar Siklus III}

Perolehan hasil belajar berdasarkan nilai pretest dan posttest peserta didik pada siklus III, dapat dilihat pada tabel 7, berikut:

Tabel 7. Perolehan Nilai pre test dan post test peserta didik

\begin{tabular}{|l|r|r|r|r|r|r|}
\hline \multirow{2}{*}{ Nilai } & \multicolumn{2}{|c|}{ Siklus I } & \multicolumn{2}{c|}{ Siklus II } & \multicolumn{2}{c|}{ Siklus III } \\
\cline { 2 - 7 } & Pretest & Posttest & \multicolumn{1}{c|}{ Pretest } & \multicolumn{1}{c|}{ Posttest } & Pretest & Posttest \\
\hline Max. & 65 & 80 & 80 & 85 & 80 & 90 \\
\hline Min. & 0 & 40 & 45 & 50 & 55 & 60 \\
\hline Rerata & $\mathbf{2 7 , 6 4}$ & $\mathbf{6 5 , 5 6}$ & $\mathbf{6 1 , 9 4}$ & $\mathbf{6 9 , 6 9}$ & $\mathbf{6 7 , 8 3}$ & $\mathbf{7 5 , 4 7}$ \\
\hline
\end{tabular}

Sumber: Hasil Pengolahan Nilai Pre Test dan Post Test Siklus I, II, dan III. 
Pada tes awal pada siklus I, diperoleh rata-rata nilai peserta didik yaitu 27,64 dengan nilai tertinggi yaitu 65 dan untuk yang terendah yaitu 0 artinya semua peserta didik tidak memenuhi KKM, sedangkan untuk nilai pre test pada siklus II diperoleh rata-rata nilai peserta didik yaitu 61,94 dengan nilai tertinggi yaitu 80 dan untuk yang terendah yaitu 45 artinya masih banyak peserta didik yang tidak memenuhi KKM, namun pretest yang dilaksanakan pada siklus III mengalami peningkatan ketuntasan hasil belajar jika dibandingkan dengan siklus-siklus sebelumnya dengan nilai mean 67,83 .

Hasil posttest peserta didik yang mengalami peningkatan dari siklus sebelumnya dimana terdapat peningkatan rata-rata ketuntasan belajar dari siklus 1 yang hanya mencapai 65,56 pada siklus II meningkat menjadi 69,69 dan siklus III meningkat menjadi 75,47.

Hasil pretest dan posttest peserta didik kelas VII-1 masih sudah mengalami peningkatan jika dibandingkan dengan siklus sebelumnya dan persentase ketuntasan hasil belajar pada siklus II mencapai $52,78 \%$ meningkat menjadi $80,55 \%$ dimana terdapat 29 peserta yang telah memenuhi KKM dan 7 peserta didik yang memperoleh nilai di bawah KKM. Hal ini, tentunya merupakan suatu peningkatan dan suatu keberhasilan yang baik karena di siklus ketiga ini peserta didik sudah mulai terbiasa dan paham dengan materi yang disampaikan menggunakan media animasi. Hal ini dapat di katakan suatu keberhasilan karena dengan meningkatnya aktivitas peserta didik ternyata berpengaruh terhadap peningkatan hasil belajar IPS di kelas VII-1.

Pada siklus III perencanaan dan pelaksanaan lebih diperbaiki dan lebih mengolah waktu serta mengontrol peserta didik dengan baik sehingga pada siklus ini sudah tercapai kriteria yang ditentukan. Penggunaan media pembelajaran berupa media animasi dapat memperlancar interaksi antara guru dengan siswa sehingga kegiatan pembelajaran lebih efektif dan efisien. Media animasi yang ditampilkan pada setiap pertemuan dapat membantu peserta didik menyerap materi belajar lebih mandalam dan utuh. Bila dengan mendengar informasi verbal dari guru saja, peserta didik kurang memahami pelajaran, tetapi jika diperkaya dengan kegiatan melihat, menyentuh, merasakan dan mengalami sendiri melalui media pemahaman peserta didik akan lebih baik. Peran penggunaan media animasi sangat berpengaruh dalam menunjang proses pembelajaran yang dilakukan di sekolah, baik itu untuk peserta didik, guru, maupun dalam proses belajar mengajar itu sendiri.

Berdasarkan penjelasan di atas dapat diketahui bahwa penggunaan media animasi dapat meningkatkan aktivitas belajar peserta didik. Pada siklus ini peserta didik sudah mampu mengikuti pelajaran dengan baik, sehingga peserta didik lebih antusias dalam belajar. Dengan menambahkan varian games "word square" juga dapat meningkatkan aktivitas peserta didik dalam belajar hal ini dikarenakan dalam game tersebut peserta didik diberikan pertanyaan yang menuntut mereka untuk lebih teliti dan berhati- 
hati dalam menjawab pertanyaan yang sesuai dengan materi tipe-tipe hujan.

Hal ini sesuai dengan pernyataan Azhar (2011), yang menyatakan bahwa media pembelajaran dapat meningkatkan dan mengarahkan perhatian anak sehingga dapat menimbulkan motivasi belajar, interaksi yang lebih langsung antara peserta didik dan lingkungannya, dan kemungkinan peserta didik untuk belajar sendiri-sendiri sesuai dengan kemampuan dan minatnya. Adanya peningkatan nilai peserta didik dipengaruhi oleh adanya peningkatan aktivitas belajar peserta didik serta pengelolaan kelas yang semakin baik.

Menurut pendapat Mustikasari (Mustikasari, Ardiani 2008) mengatakan bahwa penggunaan media pembelajaran seperti media animasi dapat meningkatkan kualitas hasil belajar peserta didik hal ini di karenakan dengan menggunaka media animasi dapat membantu peserta didik menyerap materi belajar lebih mandalam dan utuh. Bila dengan mendengar informasi verbal dari guru saja, peserta didik kurang memahami pelajaran, tetapi jika diperkaya dengan kegiatan melihat, menyentuh, merasakan dan mengalami sendiri melalui media pemahaman peserta didik akan lebih baik.

Berdasarkan pendapat tersebut, bahwa indikator keberhasilan yang ditetapkan telah dicapai sehingga penelitian dihentikan pada siklus ketiga. Dengan menggunakan media animasi maka dapat disimpulkan bahwa media pembelajaran ini dapat meningkatkan aktivitas dan hasil belajar IPS peserta didik seiiring dengan meningkatnya aktivitas belajar tersebut maka berdampak positif bagi peningkatan hasil belajar peserta didik kelas VII-1 SMP Negeri 1 Sungkai Selatan Tahun Pelajaran 2015/2016. Hal ini senada dengan pendapat guru mata pelajaran IPS, bahwa pembelajaran IPS dengan menggunakan media animasi memang bagus sehingga dapat meningkatkan aktivitas dan hasil belajar peserta didik, penggunaan media animasi dapat menarik aktivitas.

Menurut Sardiman (2002), Media animasi adalah segala sesuatu yang dapat digunakan untuk menyalurkan pesan dari pengirim kepada penerima sehingga dapat merangsang pikiran, perasaan, dan perhatian sedemikian rupa sehingga proses belajar terjadi dapat membantu peserta didik menyerap materi belajar lebih mendalam dan utuh. Selain itu, dengan menggunakan media animasi juga dapat menarik perhatian belajar peserta didik hal ini dikarenakan, peserta didik tidak hanya mendengar informasi verbal dari guru saja, sehingga peserta didik kurang memahami pelajaran, tetapi dengan menggunakan media animasi peserta didik dapat diperkaya dengan kegiatan melihat, menyentuh, merasakan dan mengalami sendiri melalui media, dan pemahaman peserta didik akan lebih baik sehingga dapat meningkatkan aktivitas dan hasil belajar IPS peserta didik sehingga indikator penelitian ini dapat tercapai.

\section{SIMPULAN DAN SARAN}

\section{Simpulan}

1. Penggunaan media animasi dapat meningkatkan aktivitas belajar peserta didik dalam pembelajaran IPS dikelas VII-I, sehingga peserta didik lebih mudah memahami dan menganalisis materi pembelajaran 
IPS dan diperoleh peningkatan hasil aktivitas pada siklus I sebesar $52,78 \%$ dan pada siklus II meningkat sebesar $64,58 \%$ dan pada siklus III meningkat menjadi 75,69\%.

2. Penggunaan media animasi dapat meningkatkan hasil belajar peserta didik dalam pembelajaran IPS dikelas VII-I, peningkatan hasil belajar pada siklus I mencapai ratarata 65,56 dari peserta didik yang mendapat nilai $\geq 72$, pada siklus II meningkat menjadi rata-rata 69,69 dari peserta didik yang mendapat nilai $\geq 72$ dan siklus III meningkat sebesar rata-rata 75,47 dari peserta didik yang mendapat nilai $\geq 72$.

\section{Saran}

Berdasarkan hasil kesimpulan dalam penelitian ini, dapat disarankan bahwa:
1. Bagi kepala sekolah diharapkan dapat lebih memperhatikan dan memaksimalkan pengadaan fasilitas atau penggunaan media pembelajaran yang dapat menunjang pembelajaran di sekolah, agar didapatkan proses maupun hasil pembelajaran yang maksimal.

2. Bagi guru diharapkan dapat menerapkan teknik pembelajaran yang bervariasi dalam pembelajaran dan lebih memaksimalkan dalam penggunaan media pembelajaran, salah satunya dengan menggunakan media animasi atau media yang lainnya, karena media animasi dapat meningkatkan aktivitas dan hasil belajar peserta didik.

\section{DAFTAR PUSTAKA}

Azhar Arsyad. 2011. Media Pembelajaran. PT Raja Grafindo Persada. Jakarta.

Baharuddin \& Esa Nur Wahyuni. (2010). Teori Belajar dan pembelajaran. ArRuzz Media. Yogyakarta.

Gage, N.L and David C. Berliner. 1985. Educational Psychology. Gulf Publising Company. New York.

Hopkins D. 1993. A Teacher's Guide to Clasroom Research. Open University Press. Philadelphia

Kemmis, Stephen., McTaggart, R. 1998. The Action Research Planner. Third Edition. Deakin University Victoria. Australia.

McNiff, Jean. And Whitehead. 2002. Action Research, Principles and Practice, Second Edition. Routladge. London

Munadi, Yudhi. 2010. Media Pembelajaran: Sebuah Pendekatan Baru. Gaung Persada (GP) Press. Jakarta.

Mustikasari, Ardiani. 2008. Mengenal Media Pembelajaran, (Online) (http://miftahululum.net/?pilih=news\&mod=yes\&aksi=lihat\&id=16, diakses 29 Juni 2015).

Nursid Sumaatmaja. 1996. Metodologi Pengajaran Geografi. Bumi Aksara. Jakarta.

Sardiman. 2002. Interaksi dan Motivasi Belajar Mengajar. Rajawali. Jakarta.

Toto Ruhimat, dkk. (2011). Kurikulum dan pembelajaran. Rajawali Pers. Jakarta. 